\title{
The correlation between students' reading speed and students' reading comprehension of the first year students in SMAN 10 Bandar Lampung
}

\author{
Agiska Berliana ${ }^{1}$, Dedy Supriyadi ${ }^{2}$, Gita Hilmi Prakoso ${ }^{3}$ \\ Universitas Lampung, Jl. Prof. Dr. Soemantri Brojonegoro No.1 Bandar Lampung, Indonesia ${ }^{1,2,3}$ \\ ${ }^{1}$ Correspondence: agiskaberliana99@gmail.com
}

\begin{abstract}
This research employed the correlation design. This quantitative research was aimed to find out the correlation between students' reading speed and students' reading comprehension. The subject of research was thirty five students at SMAN 10 Bandar Lampung. In collecting the data, the researcher used reading speed test and multiple choices test as the instruments. Reading speed test was used to know students' reading speed and multiple-choice test was used to know their reading comprehension. The data from both instruments were analyzed by using Pearson Product Moment Correlation. The result showed that there was a significant correlation between students' reading speed and students' reading comprehension since the significant correlation was 0.000 and the $r$ value was 0.641 . The value shows the strong correlation between reading speed and reading comprehension.
\end{abstract}

Keywords: correlation, reading speed, reading comprehension.

\section{INTRODUCTION}

Reading is one of the language skills that play an important role in learning English, and it is because reading has become part of our everyday lives. According to Nunan(2006), reading is a skill that includes making sense and deriving meaning from a written text. Through reading, people are able to gain a lot of knowledge, facts, pleasure, and troubleshooting. Thus, the ability to read a text in many ways can make a huge contribution to our lives, such as the progress of the school, university, or other educational institutions.

Reading speed is a skill to read and understand the letter of the text. According to Richard (2007), reading speed is usually used to describe how fast a reader reads a text that has been known by the number of words per minute. The terms reading speed and understanding of the reading are inseparable elements. Reading speed and reading comprehension are two closely related aspects. The terms reading speed and understanding of the reading are inseparable elements. Reading speed and reading comprehension are two closely related aspects.

Comprehension is a crucial part of the reading process. According to Miller(1971), comprehension is built upon both word recognition and association and cannot effectively take place unless the reader first is efficient in these two aspects of reading. Reading cannot be separated from comprehension because the purpose of the result of the reading activity is to comprehend what has been read. Reading without understanding is useless.Understanding the text is a way of answering the questions referred to. Arab(2009) explains that when we read slowly and excessively, the understanding of the text will be hampered. Thus, if we read slowly, comprehension will also be slow. Especially, if we read slowly to excess, there will be regression or repetition where readers have to repeat what they read. 
Reading speed has influenced the reading comprehension made by the students. The students' reading speed also determines the students' ability to comprehend the text. They have a great influence on success in learning reading skills. It can also give a positive or a negative effect on the students' reading comprehension because all the students have different reading speeds. Relate to the student way to comprehend reading text, the researcher has an opinion that it is important to do a research about students' reading speed and reading comprehension. It is supported by Grabe and Stoller(2002) who state that vocabulary, reading fluency, and reading rate is central to skill reading.

Many studies have been conducted that show that reading speed affects students' reading comprehension. Humaira et. al.(2017)states that the result reveals that there was a significant correlation between reading speed and reading comprehension. The students' reading speed affects students' comprehension achievement. If we read the text slowly and excessively, the interpretation of the text would be hindered. The quicker we learn, the more we understand. Nurnisa(2018)says that there is no a significant correlation between students' reading speed and their reading comprehension. Their data showed that students' reading speed has a slow category and their comprehension has a fair category.

In this study, the research is focused on identifying the correlation between students' reading speed and students' reading comprehension. The difference between those researches and this study is that the researcher tried to hold a new investigation by combining all of the topics by using correlational study ex post facto.From the background of research, the researcher conducts a research about the correlation study between reading speed and reading comprehension.

\section{METHODS}

This research applied a quantitative design. Ex post facto is the specific design since this research is correlation study. In determining the sample, the researcher used purposive sampling. The researcher selected X MIPA 2 as the subject of the research. Based on the early observation (internship) at SMAN 10 Bandar Lampung was the most responsive and active class among all the first-year students. In collecting the data, the researcher used reading speed test and reading comprehension test.Then, the result of students' word per minute and the score of reading comprehension test were analyzed by using Pearson Product Moment to know the correlation.

\section{RESULTS AND DISCUSSIONS \\ Result}

This chapter describes a general description of data gained by the researcher during the research. The data were collected from the result of the correlation between students reading speed and students reading comprehension. The validity and reliability test had been conducted before the researcher administered the test. Before answering the research question of this study, the data description of this research has been obtained.

\section{The Result of Reading Speed Test}

The reading speed test was conducted on March, 15 2021. This test was conducted to measure the reading speed and calculate the student's WPM (Word Per Minute). This test had conducted by using zoom meeting. The result of the WPM was showed that the range of the speed is between 77 146 wpm.

\section{The Result of Reading Comprehension Test}


Reading comprehension test was given on Monday, 15 March 2021. There were 40 items and the test was in the form of multiplechoices. The researcher distributed the test through Google Class Room and the students answered the test through Google form. After researcher collected their answers, total of correct answers were calculated with Arikunto's(1997) formula.

The result showed that the respondents were 35 students. By the result of reading comprehension test, the minimum score was 45 and the maximum score was 90 . Lastly, the mean of score was 71.3.

\begin{tabular}{|lccc|}
\hline No. & Class Boundaries & Frequency & Percentage \\
\hline 1. & $76-90$ & 7 & $20 \%$ \\
\hline 2. & $61-75$ & 18 & $51 \%$ \\
\hline 3. & $45-60$ & 10 & $29,6 \%$ \\
\hline
\end{tabular}

From the table above, the researcher divided the students' score into three groups. In the first group, there were 7 students have ranged score 76-90 which means they have the highest scores. On other hand, 10 students have ranged score 45-60 in the last group which means they have the lowest score among the students.

\section{The Correlation between Students' Reading Speed and Students' Reading Comprehension}

After testing the students' reading speed and calculating the score of students' reading comprehension, the researcher analyzed the data through Pearson Product Moment Correlation in order to know whether there is correlation between students' reading speed and their score in answering the question.

\begin{tabular}{|c|c|c|c|}
\hline \multicolumn{4}{|c|}{ Correlations } \\
\hline & & Reading Speed & $\begin{array}{c}\text { Reading } \\
\text { Comprehension }\end{array}$ \\
\hline \multirow[t]{3}{*}{ Reading Speed } & Pearson Correlation & 1 & $.641^{* *}$ \\
\hline & Sig. (2-tailed) & & .000 \\
\hline & $\bar{N}$ & 35 & 35 \\
\hline \multirow[t]{3}{*}{ Reading Comprehension } & Pearson Correlation & $.641^{* *}$ & 1 \\
\hline & Sig. (2-tailed) & .000 & \\
\hline & $\mathrm{N}$ & 35 & 35 \\
\hline
\end{tabular}

The table above describe about the correlation between students' reading speed and students' reading comprehension. It can be seen that the score of the significance between reading speed and reading comprehension is $0.000<0.05$. Furthermore, the $r$ value was 0.641 which indicated very high correlation.

\section{Hyphothesis Testing}

After the researcher have collected and analyzed the data, the researcher investigated whether the hypothesis would be accepted or not. Based on the result, the researcher obtained the $r$ value was 0.641 and the significant correlation coefficient was 0.000 based on table 4.7 result of Pearson Product Moment. Additionally, it acquired two tailed and level of significant was 0.01. By all 
means, the $\mathrm{H} 1$ was accepted as $0.000<0.050$. Hence, there was a significant correlation between students' reading speed and students' reading comprehension.

\section{Discussion}

The research question was to find out whether there was any significant correlation between students' reading speed and students' reading comprehension. This research has two instruments: reading speed and reading comprehension test. The researcher analyzed it through Statistical Package for Social Science (SPSS) in order to answer the research question.

According to the result, it represents that correlation coefficient was 0.000 and $\mathrm{r}$ value was 0.641 . It indicated that there was a significant correlation between students' reading speed and students' reading comprehension since $0.000<0.050$. The value shows the strong correlation between reading speed and reading comprehension. Another way to see the correlation is from the stars symbol in the out-put. From the output, it can be seen that the score of Pearson Correlation which is related between each variable has stars symbol, it means there is a significant correlation between two variables.

To support this finding,Nuttal(1982) said that reading speed and reading comprehension are two elements that are closely related. The students' reading speed affects the students' comprehension achievement. Reading speed has influenced the reading comprehension made by the students. The students' reading speed al-so determines the students' ability to comprehend the text. Added by Browning(2003) that readers are able to concentrate better which leads to greater comprehension.

Moreover, the finding is also in line with Hernowo (2003) that students can be called fast readers if they are able to read text quickly and have a high or precise level of understanding. Speed is not enough to make the reader understand what they read.The reader needs comprehension their skill. Reading speed has a great influence on students' reading comprehension. As Whitely in Hidayat(2019)said that to comprehend what the students read, they need to consider their reading speed as it helps the learning process to locate important information quickly. Hence, students' comprehension suffers.

Dechant and Smith(1961)share similar ideas that the reading speed should require a reading level that is concerned with the comprehension because the reading speed is nothing without the comprehension what is being read. They have a great influence on success in learning reading skills. It can also give a positive or a negative effect on the students' reading comprehension because all the students have different reading speeds. If we read slowly and excessively, the understanding of the text will be hampered. Reading speed will help someone in comprehending the reading text, reading speed without comprehension is worthless.

Furthermore, several studies have been conducted to investigate the correlation between students' reading speed and students' reading comprehension. The finding was confirmed by the study of Humaira et. al. (2017)which reported this study revealed that there is a significant correlation between reading speed and reading comprehension. The value also showed the strong correlation between the variables. It was found that $r$ value is greater than $r$ table, that is $0.74>0.355$.

In line with this study, the study of Tanjung (2016)stated that there was a correlation between students' reading speed and students' reading comprehension. This study revealed that there is a significant correlation between students' reading speed and students' reading comprehension where 
the score of the data showed 0,000 or it means lower than 0,05. Based on the previous study above, it can be concluded that reading speed has a positive effect on reading comprehension.

However, there is a difference between this study and the previous study namely, in this study the result of this study is there was a correlation between students' reading speed and students' reading comprehension. But the study of Datunsolang(2013)said that there was no significant correlation between students' reading speed and students' reading comprehension. It was also strengthened by analyzed the effect speed reading as $\mathrm{X}$ variable to reading comprehension as $\mathrm{Y}$ variable, it is found that speed reading is only effects $33 \%$ to $\mathrm{Y}$ variable. It means that reading speed cannot give good effect to reading comprehension. The other difference is in this study the researcher used high school students as the research subject, but in the study of Datunsolang(2013)the researcher used college student as a research subject.

The findings of this study provide some insight into the reading teaching process in the classroom. The teacher must take into consideration each student's reading speed. The teacher should also be able to come up with creative ways to teach students reading skills. The teacher is expected to adapt their teaching strategies to their students' reading levels and to employ appropriate strategies to boost the students' reading performance.

From the explanation above, it concluded that the significance of the correlation between students reading speed and their reading comprehension could vary. The majority of the journals gathered by the researcher show that there is a significant correlation between both variables. In addition, the condition and history of the research object may be considered to be researched.

\section{CONCLUSIONS AND SUGGESTIONS Conclusion}

Reading is an interactive process that requires the ability to draw meaning by analyzing word by word in the text and then extracting as much information as the writer puts into it as possible. Reading is a process that takes time to complete. The time spent to read called reading speed or reading rate indicated with wpm (words per minute). Then comprehension comes up as the result of the reading. Reading comprehension is the understanding of the meaning of a written text that occurs when the reader extracts and integrates information from the text.

Based on the result of analyzing data, it can be stated that there was a significant correlation between students' reading speed and students' reading comprehension was proved by that coefficient correlation was lower than $0.50(0.000<0.050)$. It can be concluded that, this result has answered the research question.

\section{Suggestions}

The researcher anticipates that the findings of this study will assist teachers in teaching reading skills. Teachers are expected to consider the fact that each student's reading level and comprehension may differ. As a result, the teacher must train students' reading speed and comprehension.

This study is limited to reading comprehension in descriptive text. The researcher suggested that the future research can look into other types of reading text like narrative text, recount text and et cetera. The researcher also expects for the next researcher to examine the external and internal factors of students if the reading speed and reading comprehension students classified as low or high. 


\section{REFERENCES}

Arab, O. (2009). Enhancing reading speed for comprehension in EFL classes. Unpublished thesis at University of Constantinte.

Arikunto, S. (1997). Prosedur penelitian: suatu pendekatan praktek. PT Rineka Cipta.

Browning, J. (2003). Why teacher should use timed reading in ESL classes. The Internet TESL journal , 1-13.

Datunsolang, A. (2013). The correlation between students' reading speed and students' reading comprehension. Unpublished thesis at State University of Gorontalo.

Dechant, E., \& Smith, H. P. (1961). Psychology in teaching reading. Prentince Hall.

Grabe, W. D., \& Stoller, F. L. (2002). Teaching and researching reading. Longman.

Hernowo. (2003). Quantum reading. MLC.

Hidayat, D. (2019). The effect of speed reading on students' reading comprehension. Journal of English Education Studies , 12-22.

Humaira, S. E., Komariah, E., \& Inayah, N. (2017). The correlation between students' reading speed and their reading comprehension. Research in English and Education, 144.

Miller, W. (1971). Identifying and correcting reading difficulties in children. The Center for Applied Research in Education.

Nunan, D. (2006). Practical English language teaching: young learners. McGraw Hill.

Nurnisa, D. (2018). The correlation between reading speed toward student comprehension at eight grades of Pondok Pesantren 2018/2019.[Doctoral dissertation, UIN Sulthan Thaha Saifuddin Jambi].

Nuttal, C. (1982). Teaching reading skills in a foreign language. Heinemann Educational Books.

Tanjung, K. S. (2016). The correlation between students' reading speed and reading comprehension of third semester students of english department of STAIN Gajah Putih Takengon. English Education, 5, 79. 